\title{
COMMUNICATIVE LANGUAGE TEACHING: SOME OF THE CHALLENGES FOR TEACHER TRAINERS IN SOUTH AFRICA
}

\section{Elaine Ridge}

Communicative language teaching presents a number of challenges to those involved in teacher training. This article takes the view that the focus should be on education, rather than training. The challenges inherent in four areas are given particular attention: the view of language; the view of teaching; the view of language learning and the view of the learner. The final section, argues that courses should be proactive, enabling students to review the current teaching approach critically and adapt it to the particular contexts in which they do their teaching.

Kommunikatiewe-taalonderrig stel 'n heel aantal eise aan diegene wat betrokke is by onderwyseropleiding. Hierdie artikel voer aan dat die fokus op opvoeding, eerder as opleiding, behoort te val. Die klem val op eise wat eie is aan vier terreine van kommunikatiewe-taalonderrig: die siening oor taal, die siening oor onderrig, die siening oor taalonderrig en die siening oor die leerder. Die laaste gedeelte pleit dat kursusse proaktief moet wees om studente in staat te stel om die huidige onderrigbenadering krities to beskou en dit aan te pas by die besondere konteks waarin hulle onderrig gee.

\section{INTRODUCTION}

Paradoxically, both the strengths and the weaknesses of Communicative Language Teaching (CLT) lie in its broadness. The contention made by Richards and Rogers (1986:66) that "there is no single text or authority on it, nor any single model that is universally accepted as authoritative" remains valid. Nothing is prescribed, nothing is proscribed. As Bernes (1990: 103) points out, its strengths emanate from the freedom and flexibility it provides, characteristics which are necessary if the teacher is to embrace social and cultural diversity. Founded as it is on "an understanding of the nature of communication", it honours the way in which the norms for communication vary from context to context. Its weaknesses lie in a lack of rigour that has tempted followers into confusing the notions which inform it with rules.

This article explores some of the challenges teacher "trainers" in South Africa face in enabling student teachers to discover the full potential of CLT, and to avoid its pitfalls.

\section{EDUCATION AND TRAINING}

The primary need is to "educate" rather than "train" student teachers. A facilitative rather than an informative mode is required. Widdowson (1990: 66) argues for a "process of pragmatic mediation" in the form of discussion of issues of pedagogic concern guided by "principles" which are supported by theory and research.

There are a number of factors which make such an educative focus difficult to achieve. First, language teacher trainers in South Africa are generally given too little time for them to afford their students a basic grounding in Applied Linguistics. Secondly, some of the lecturers themselves lack a comprehensive understanding of the field and/or have little "hands-on" contact with the exigencies of teaching in schools. In any of these circumstances, there is a strong danger that the cause of a 
favourite "method" will be espoused, or that "recipes" will be offered, justified by a declared interest in being "practical". What students are likely to have at the end of their course, then, is a set of glib "answers" rather than the means to assess a situation and then draw up a suitable curriculum for the particular learners in a particular language context.

Johnson (1989) has a different perspective. In his terms, training at its best is essentially educative.

In a coherent curriculum, teacher training would clarify policy aims as expressed in the syllabus, would show how ends and means relate, how they are embodied in the teaching programme and how particular classroom procedures complement the programme materials and optimise learning opportunities.

(Johnson 1989:9)

Although this may appear to honour an implementational role for the trainer, Johnson (1989) argues that an active and developmental role is necessary. Clarification of the policy aims requires an active role in going beyond the sketchy information provided in syllabuses or curriculum policy documents to give students a firm grasp of the underlying theory which underlies it. Professional training enables students to make appropriate choices and gives them a repertoire of skills and techniques to implement these choices.

Johnson highlights the dangers of restrictive agendas teacher trainers at both ends of the spectrum: at one extreme, specialists in applied linguistics, and at the other, superb practitioners. The former tend to be rather dismissive of the curriculum, urging resistance to the official view, and even revolution. The latter tend to impart skilful techniques, but fail to give any sense of the broader purposes of the curriculum against which any programme must be tested. Both Pennington (1989) and Breen et al. (1989) are at one with Johnson that the teacher-training curriculum is inextricably related to the school curriculum in which it is embedded.

To illustrate the challenges to teachers educators/trainers in the complementary role advocated above, four key aspects of Communicative Language Teaching will be explored: view of language, view of teaching, view of language learning, and view of the learner.

\section{VIEW OF LANGUAGE}

Communicative Language Teaching is based on a view of language as communication. It draws on the work of neo-Firthian functional or systemic linguists: pragmatics, discourse analysis and studies of social interaction.

Although it has a "rich, if somewhat eclectic base" (Richards and Rogers 1986:71), there is a tendency among some practitioners to adopt a reductionist view of language as solely communication. This derives from a narrow view of communicative competence. Rudolf Botha (quoted in Ridge 1992) has warned of the dangers of this position. Perhaps Hymes's discussion of the knowledge and abilities a speaker needs to be communicatively competent in a speech community would be useful at this point. For communication to be effective, a participant needs to know

1. whether (and to what degree) something is formally possible;

2. whether (and to what degree) something is feasible in virtue of the means of implementation available

3. whether (and to what degree) something is appropriate(adequate, happy, successful) in relation to a context in which it is used and evaluated; 
4. whether (and to what degree) something is in fact done, actually performed, and what its doing entails.

(Hymes 1972:281)

Canale and Swain's careful detailing of the "knowledges" which make up communicative competence provides a useful expansion. They specify discourse competence, grammatical competence, strategic competence, and sociolinguistic competence (Canale 1983). However, they perhaps lack the perspective of proficient performance advocated by Taylor (1988) and Bachman (1990).

A major challenge for teacher trainers is to broaden the students' view of language. Their pupils have to be equipped linguistically for full participation in the range of human activities. Recommendations in syllabus and related documents to "focus on meaning rather than on form" require that meaning be accorded a central role, with a strong emphasis on interaction. However, categories of functional and communicative uses must be viewed along with the grammatical and structural features which can serve as their vehicles.

Here too we have to guard against reductionism. A recent article in a British newspaper comments on an over-simple sentiment excerpt from the National Curriculum in Britain:

"Spoken standard English differs from its written form in that it may consist of sequences of clauses rather than complete sentences and contain hesitations and false starts." This isn't true. Written English is full of bits and pieces of sentences: in scripts, dialogues, advertisements and even prose like this. In addition, hesitations and false starts are true of all spoken English, not just standard usage.

The trouble with - and the glory of - language is that it won't (indeed it can't) be bound by rules. They do exist but not like standard gauge railways. Sometimes we may want to write aint and not is not and even isn't, to make a point or produce an effect that lies beyond the "regular" standard. There are many areas where people take sides or can't see where the problem is - like avoiding generic "he" or splitting infinitives. Nobody can lay down absolute laws about these things. Nobody. No government. No country. No teacher. No guru of grammar or style.

Standard English exists, but it is fuzzy round the edges, and young people need to learn this fact along with everything else that can help them handle loaded social weapons.

(Tom Mc Arthur, Guardian, March 1993)

The McArthur text illustrates the creative nature of language and the false divisions that are made between spoken and written language and standard and non-standard English. It provides a rich example of the layers of meaning in a text. While breaking conventional format constraints it also, ironically, erodes the simplistic view that form is not a carrier of meaning. not on form. It provides a context for Widdowson's uncompromising position that "a communicative approach properly conceived does not involve the rejection of grammar" (Widdowson 1990: 98). The teaching of grammar is not to be confused with a return to the arid terrain of formal grammar, 
but rather aims to provide learners with a powerful resource, so that they can achieve meaning in a purposeful way and interpret it as well.

Properly understood, a communicative approach this approach will make it possible for our students to develop a sophisticated understanding of language in action.

Halliday's functional account of language use, which played a seminal role in the early development of CLT, is still helpful. He distinguishes:

1. the instrumental function: using language to get things

2. the regulatory function: using language to control the behaviour of others

3. the interactional function: using language to create interaction with others

4. the personal function: using language to express personal feelings and meanings

5. the heuristic function: using language to learn and to discover

6. the imaginative function: using language to create a world of the imagination

7. the representational function: using language to communicate information.

In CLT, however, function must be accorded a central role, with a strong emphasis on interaction. However, categories of functional and communicative uses must be viewed along with the grammatical and structural features which can serve as their vehicles.

A less complex view of language may have serious implications. Brumfit (1985: 155) bluntly warns:

Over-emphasis on linguistic creativity, without any reference to what it is for and what it expresses, may be the most dangerous current constraint on the language classroom.

And Rutherford (1987: 147) reminds us that language plays an integral role in virtually every conceivable human activity. It is used for thought, problem solving, play, dreaming, displays of group solidarity, and deception.

The inclusive and complex view of language we have been discussing has a number of implications. Clearly, methods that use material isolated from a social context with the purpose of patterning firmly absolute rules. A comprehensive understanding of language use is called for. This will not easily be accomplished. Much of the available literature on pragmatics is accessible only to specialists. Leech and Svartvik (1985) is one of the few grammar books that explores how the meaning potential intrinsic in language form is realized in the pragmatic achievement of meaning. However, even it has deficiencies. It is initially formidable. It is probably too technical in some respects. And it is short on practical illustrations.

Perhaps the major challenge here is to produce simple materials which illustrate discourse in action, demonstrating the nature and function of sociolinguistic rules in concrete form, and giving a clear "context of meaning" to the terms concerned. This would obviously involve exploring the nature of interaction between the participants in a particular context and the way in which meaning is negotiated and realised with greater or lesser success depending on a number of factors. 
Without a rich understanding of language, future teachers are likely to have only a facile understanding of key concepts like "appropriate" and "standard". In a South Africa which increasingly requires an honouring of multilingualism, this would be a serious shortcoming in teachers, especially as they will have to make complex decisions on the status "non-standard" varieties enjoy in the classroom.

In a bold move in Britain, Ron Carter and others, preparing for the implementation of a new National Curriculum in Britain, tackled the need to offer children an understanding of language. Their LINC project articulates the view that language is a "loaded weapon" - not a simple vehicle of exchange:

* As humans we use language primarily for social reasons, for a multi-variety of purposes.

* Language is imbued with dynamism and varies from one context to another and from one set of uses to another. Language also changes over time.

* Language is penetrated with social and cultural values and also carries meanings related to each user's unique identity.

* Language reveals and conceals much about human relationships. There are intimate connections, for example, between language and social power, language and culture and language and gender.

* Language is a system and is systematically organised.

* Meanings created in and through language are often problematic; they can constrain us as well as liberate us.

* Language users must constantly negotiate and renegotiate meanings.

South Africans may question the relevance of a document designed to meet the needs of a National Curriculum in Britain. I would contend in reply that the view of language expressed here lies at the heart of the support for multilingualism and the removal of an L1/L2 distinction in SA today. Failure to take full account of this view of language could mean a failure to empower our pupils. In an earlier paper (Ridge 1992) I argued for the need to heed the warnings of Pierce (1991) and Ndebele (1987) that language teachers may unwittingly be doing their pupils a profound disservice by failing to take account of the social values embedded in ways of using language.

Those who have claimed to espouse CLT have often tended towards a "top-down" view of teaching. In their terms, teaching is adjudged "good" or "effective" to the extent to which it reflects a set of beliefs, principles or values. In this sense it is prescriptive. There are obvious challenges in this for teacher educators. In a paper presented at the 1992 TESOL conference, Widdowson referred to the 3 Ps (pundit, Philistine, and performing monkey) as representing the dangers by the wayside. The teacher-trainer/educator must guard against adopting the position of pundit, promoting received wisdom, rather than provoking inquiry; or against being a Philistine who rejects theory in favour of tips from existing practice and offers a set of slogans; or against being a performing monkey who gives hegemonic status to specific ideas and techniques. 
In the South African context, there is a vital need to have teachers in the field who are able to adapt what they teach and the means they use to do so to meet the needs of learners in particular circumstances. The models of CLT which we have inherited from Europe and America derive from a context quite different from the ones in which our students will find jobs. The models operate on the assumption that the size of the classes (of pupils) will be small ( 15 or fewer), making it possible for group and pair work to be managed very effectively, with close monitoring and extensive teacher participation. Clearly, an important challenge would be to ensure that careful account has been taken of the assumptions which underlie particular recommended techniques and practices before urging their adoption. Widdowson (1990: 199) suggests that a possible way of doing this is by engaging in "a process of pragmatic mediation" in which real teaching contexts are the starting point for a methodology that is geared not only to the competence of those participating in the learning situation, but also to the constraints of the learning situation: the institutional context, learner expectations and the demands of society. Attempts to operationalise uncontextualised learning principles as an objective of teacher education will inevitably founder, for classrooms are not more alike than they are different.

In pursuing this matter further it is useful to take account of the analysis of education and training for teachers by Pennington (1989). She discerns two streams in the education and training of language teachers: the competency-based model and the holistic model. While the holistic approach emphasises personal development, creativity, judgement and adaptability, the competency-based model is seen as having the following characteristics:

1. The job of teaching is analysed into tasks that must be performed.

2. The abilities required for these tasks must be specified.

3. The skills or techniques through which the abilities are expressed must be clearly described.

4. Training situations and exercises for the development of each skill must be worked out in detail.

(Smith 1969: 77)

Clearly holistic approaches will encourage the development of the ability to analyse a situation and adapt practice accordingly, rather than merely for a specific situation (Larsen-Freeman 1983: 265), but they will have to be supplemented with competency-based approaches to develop particular skills or techniques.

The ability to adapt may also depend in part on preferred cognitive teaching style. Van der Walt (1991) highlights the differences in characteristic behaviour that mark the distinctions between field dependent and field independent teachers. In short, the field-independent teacher is analytic in his or her approach to language teaching and prefers teacher-directed learning, with less personal involvement or interaction (Ellis 1985; Hansen and Stansfield 1982). The field- dependent teacher enjoys personal involvement and the interaction of group and open classroom discussions (McLaughlin 1985; Hansen and Stansfield 1982). Clearly, teachers should ideally have elements of both field dependence and field independence in their teaching style. As Wright (1987: 52) reminds us, the roles of manager and instructor complenient each other. Whatever the case may be, teacher trainers must give their students sufficient opportunities to be self- reflective, so that they are able to meet the needs of pupils whose cognitive style is different from theirs or the demands of a teaching situation which requires a different approach from the one that is natural for them. Oliva (1982) and Cornett (1983) both argue the importance of modifying a strong 
field-independent orientation. Clearly, heuristic learning would constitute a very effective way of doing so (Golebiowska 1985).

An understanding of the language learning process is perhaps the most complex and elusive of the aspects considered in this paper, and the aspect in which CLT practice has been least sophisticated. For the purposes of this discussion "proficiency" will be seen as the "product" of language learning and Second Language Acquisition (SLA) will be seen as the "process".

Pressing practical demands, especially in Europe, meant that the CLT movement spread rapidly, moving ahead of SLA research. It emphasised proficiency and neglected process. At best we can speak of theories of language learning processes that are compatible with communicative teaching, rather than ones from which it originates. Two questions arise: to what extent can SLA research be trusted, and to what extent can it be applied to language pedagogy? There are at least four options propounded by scholars in the field:

1. The results of SLA research cannot be safely applied to language pedagogy because they are too uncertain.

2. SLA research provides a basis for teacher "education" but not for teacher "training". That is, it can help teachers develop reasonable expectations about what they can achieve in their teaching, but it cannot be used to tell them how to teach.

3. SLA research provides information and actual data that can be used in the construction of tasks designed to raise teachers' awareness of the likely relationship between teaching/learning behaviours and L2 acquisition.

4. The results of SLA research (and, in particular of classroom-orientated research) provide "hard evidence" which should be used to advise teachers about what techniques and procedures work best.

The full continuum from "don't apply" to "do apply" is represented here. And we are all aware of the distorting effects of "adulation", on the one hand, and "firm rejection" on the other. Krashen's theories elicited enough controversy for us to know that confident assessments of the value of "research" are elusive. It seems that data problems continue to beset SLA research (Ellis 1994), although much more is known about some aspects than about others. And it remains true that very little SLA research has been conducted in what Widdowson (1990) describes as the "concrete and varied" situation of the classroom.

The challenge is to place student teachers in a position where they can see both the limitations and the value of the research. With this kind of knowledge they will be able to use salient insights to attempt solutions to their own pedagogic problems (Widdowson 1990: 66), or be stimulated into making practical use of research by exploring the relationship between the techniques and procedures they use and the learning that is achieved. It should also place them in a position to draw confidently on the "best" information available (using Long's metaphor, to be like doctors who need to draw on research findings). Ellis (1990: 204) usefully suggests that research is only likely to provide insights or clues about what happens when teachers try to intervene in the process of language learning. "We will always need to 
interpret clues with the help of common sense based on the practical experience of what works and does not work in the classroom." .

\section{VIEW OF THE LEARNER}

Currently there is a strong emphasis on the role of the learner. Terms such as "learner-centred" and "learner-focused" dominate attempts to describe the ideal approach. There is an implicit belief that the learner must "contribute as much as he gains" (Breen and Candlin 1980: 110). Teasing out the implications of a participatory process such as this holds obvious challenges. There is the paradox to be understood that though the balance of power will inevitably shift, the teacher is no less authoritative. In respecting the view of the learner which CLT encourages, teacher educators have to create the conditions which will allow teachers-in-the-making to adjust their attitudes to teacher and learner roles and to develop ways of allowing fully for learner initiatives.

THE NEED TO BE PROACTIVE

Thus far we have considered the ways in which we can equip our students to meet the demands of CLT. This assumes that CLT represents a satisfactory solution to the needs of South African pupils. However, there is evidence from all over the world of disillusionment with CLT or of a sense that it has not justified the claims made for it in the seventies and eighties. Here in South Africa, the difficulties in implementing it satisfactorily have been highlighted (Ridge 1992, Jessop 1994, Makoni 1994, van der Merwe 1994). Perhaps most significantly, we are in no position to provide most schools with teachers whose own language proficiency is of a high standard. Furthermore, the needs of second language learners are varied. On the one hand there is a strong need to teach English for very specific purposes, but on the other hand the role of the language as a lingua franca means that the ability to use it proficiently in a number of contexts must have a high priority. This requires courses of some sophistication.

The goals of CLT should continue to influence us whatever new approaches succeed it: teachers have to teach language so that learners are better able to use it in the full range of social situations.

\section{CONCLUSION}

A training system that aims to produce teachers who adopt a particular pattern of teaching has serious limitations. No single "method" can be said to offer the best approach for all teachers and in all circumstances. We have to ensure that student teachers are provided with a repertoire of skills and techniques and that they have sufficient understanding of the necessary theoretical insights to make principled decisions in the best interests of the particular pupils/students they teach.

Like Protherough and Atkinson (1991), I find Margaret Meek sums up the best conditions for ensuring that the teaching of English will be in good hands.

Contrary to popular belief, teachers are made not born. They become expert as experts do, by a progressive understanding of what they are about.... What all teachers need is the chance and the possibility to develop their understandings in the company of their professional peers and others whose 
expertise enhances their own. They need regular challenging encounters with new ideas, new pedagogies, new research, and other teachers. It takes money and it takes time, but nothing else will suffice (Meek 158 (quoted in Protherough and Atkinson 1991: 130).

Inherent in this is the greatest challenge of all for teacher educators: to ensure their own ongoing development both as teachers and as educators.

\section{REFERENCES}

BACHMAN, L. 1990. Fundamental considerations in Language testing. Oxford: Oxford University Press.

BERNES, MS. 1990. Contexts of competence: social and cultural considerations in communicative language teaching.

BREEN, M AND CANDLIN, C 1980. The essentials of a communicative curriculum in language teaching. Applied Linguistics 1(2): 99-112.

BREEN, M, CANDLIN, C, DANN, L \& GABRIELSEN, G. 1989. The evolution of a teacher training programme. In Johnson, RK (ed.): 111-135.

BRUMFIT, C. 1985. Creativity and constraint in the language classroom. IN Quirk, $\mathrm{R}$ and Widdowson, $\mathrm{HG}$ (eds). English in the world: teaching and learning the language and literature. Cambridge: Cambridge University Press.

CANALE, M. 1983. From communicative competence to language pedagogy. In Richards, J and Schmidt, R.

CORNETT, CE. 1983. What you should know about teaching and learning styles. Bloominton: Phi Delta Kappa.

ELLIS, R. 1994. The study of second language acquisition. Oxford: Oxford University Press.

GOLEBIOWSKA, A. 1985. Once a teacher, always a teacher. ELT Journal 39(4):274-278.

HANSEN J AND STANSFIELD C. 1981. The relationship between field dependent-independent cognitive styles to foreign language achievement. Language Learning 31:349-67.

HYMES, D. On communicative competence. In Pride, JB. Sociolinguistics. :26993.

JESSOP, T. 1994. An initial investigation into the teaching and learning of English in primary and secondary schools.

JOHNSON, RK. 1989. The second language curriculum. Cambridge: Cambridge University Press.

LEECH, G AND SVARTVIK; J. 1987. A communicative grammar of contemporary English. London: Longman. 
MCARTHUR, T. 1993. Language used as a loaded gun. Guardian, 20 April 1993 reprinted in English Today, 38: 12-13.

MCLAUGHLIN, 1985. Second language acquisition in childhood. Vol. 2: Schoolage children. Hillsdale, NJ: Lawrence Erlbaum.

MAKONI, S. 1994. Private correspondence.

NDABELE, N. 1987. The English language and social change in South Africa. The English Academy Review. 4:1-16.

OLIVA, PF. 1982. Developing the curriculum. Boston: Little and Company.

PENNINGTON, MC. 1989. Faculty development for language programs. In Johnson, RK (ed.): 91-110.

PIERCE, B. 1991. Towards a pedagogy of possibility in the teaching of English internationally: people's English in South Africa. TESOL Quarterly 23(3):401-20.

PROTHEROUGH, R AND ATKINSON, J. 1991. The making of English teachers. Milton Keynes: Open University Press.

RICHARDS, JC AND NUNAN, DN. 1990. Second language teacher education. Cambridge: Cambridge University Press.

RICHARDS, JC AND ROGERS, TS. 1986. Approaches and methods in language teaching: a description and analysis. Cambridge: Cambridge University Press.

RIDGE, E. 1992. Communicative language teaching: time for review? SPIL PLUS $21: 95-108$.

RUTHERFORD, WE. 1987. Second language grammar: learning and teaching. London: Longman.

SMITH, BO. 1969. Teachers for the real world. Washington, DC: American Association of Colleges for Teacher Education.

TAYLOR, G. 1988. The meaning and the use of the term "competence"" in linguistics and applied linguistics. Applied Linguistics 9:148-68.

VAN DER MERWE, DJ. 1994. The problems of implementing the communicative approach to English as a second language. Unpublished M Ed, University of Stellenbosch.

VAN DER WALT, JL. 1990. The role of the teacher in communicative language teaching. Journal for Language Teaching, 24(1): 28-37.

WRIGHT, T. 1987. Roles of teachers and learners: Oxford: Oxford University Press.

WIDDOWSON, HG. 1990. Aspects of language teaching. Oxford: Oxford University Press.

WIDDOWSON, HG. 1992. ELT and EL teachers: matters arising. ELT journal 46(4): 333-339. 